\title{
Ultrastructural Changes in the Uterine Epithelium Following the Stimulation with Uterine-RNA
}

\author{
Kaname HAYASHI, Michinori NISHIKAWA and Wenyuan LEE \\ Department of Obstetrics and Gynecology, Kobe University, School of Medicine, Kobe, Hyogo 650, Japan \\ (Director : Professor Shimpei Tojo)
}

The ultrastructural changes of ovariectomized rat endometrium were studied after the intraluminal administration of uterine high molecular RNA, for the purpose of understanding the action mechanism of uterine-RNA from the morphological standpoint. The following pertinent findings were obtained.

Increase in the height and the number of microvilli was observed in the luminal epithelial cells 12 hours after the injection of RNA.

There was also slight enlargement of cytoplasm which contained abundant free ribosomes with some polyribosomes, the granular endoplasmic reticulum with moderately dilated cisternae and a developed Golgi complex. Furthermore, the number of the mitochondria was also increased and the nucleoli were well defined.

On the contrary, the number of lipid droplets decreased slightly but the obvious interdigitation between the basal part of the luminal epithelial cells was noted.

After 24 hours, the above-mentioned changes in the organelles were more prominent in the luminal epithelial cells. The apical vesicles were recognized and large polymorphic structures, suggesting lysosome were also observed at this period.

These findings were similar to those observed in the endometrium after the administration of estradiol-17 $\beta$.

The possible action mechanism of this uterine-RNA was discussed.

(See pp. 755 765) 


\section{Uterine-RNA 投与下の子宮内膜微細構造の変化}

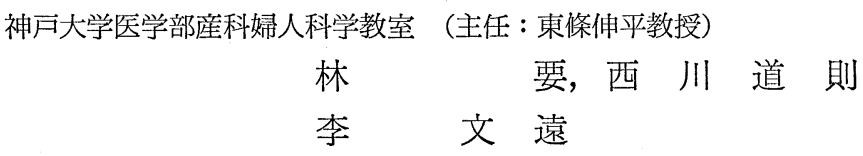

（昭和49年 1 月 5 日受付）

Uterine-RNA の作用機構を知る目的で，本 RNA を去勢ラットの子宮腔内に注入し，内膜細胞に生 ずる微細構造の変化を経時的に観察した. 表面上皮細胞では，RNA 投与12時間後に，微絨毛の数やそ の丈が増し, 細胞質肥大, polyribosome の出現, ゴルジ装置の発達や粗面小胞体の内腔拡大などが認 められた。てれらの変化は24時間後では一層著明になると共に, apical vesicle も観察された。てれら の所見は estradiol-17 $\beta$ 投与時の内膜細胞の変化と類似していた。

\section{はじめに}

Estrogen は標的器官である子宮に種々の生物学的作用を誘起するが，その生物学的作用発現の機序に関 しては, 最近 estrogen receptor さらにその gene regulation の問題, あるいは脂質代謝や細胞膜におよぼ す作用などが注目される。

てのうち特に Segal ら ${ }^{1)}$ が RNA extract の子宮内膜に対する生物学的作用の新しい測定法を開発して以 来, estrogen 投与後子宮において合成される RNA は蔵器特異的に estrogen 作用を代用するてとが明ら かにされている (Segal $~^{1)}$, Unhiem $~^{2)}$, Sugawa ${ }^{3)}$, Fencl $ら^{4)}$ ).

われわれも estrogen を前投与した去勢ラット子宮から RNA を抽出し，ての high molecular RNA を 去勢ラット子宮腔内に注入した結果, 内膜上皮細胞の高円柱状化や, ${ }^{3} \mathrm{H}$-thymidine 標識細胞の増加の認め られるとと, さらに去勢 progesterone 投与法下の遅延着床ラットに対しては着床促進作用を持つととを先 に報告した5).

このような研究結果はいうまでもなく, estrogen の生物学的効果発現機構の解明に 新しい側面を提供す るものであり，他方他の性ステロイドに関しても，O'Malley $ら^{6)}$ は progesterone の作用機序に関連して progesterone 投与によつて誘導される特殊な蛋白, avidin の存在を, また Fujii ら ${ }^{778)}$ は未熟雄性ラットに testosterone を投与し，その前立腺より抽出された RNA は去勢ラットの前立腺発育作用を有するてとを 立証している。

われわれは本研究において, uterine-RNA の作用機序を形態学的に追求する一つの試みとして, 本RNA を去勢ラットの子宮腔内に注入し，その内膜細胞に生ずる微細構造の変化を経時的に観察したので，以下得 られた所見を報告したい.

\section{実 験 方 法}

\section{Biologically active RNA の作成}

Uterine-RNA の作成は両側卵巣摘除後 3 週間以上経過した Wistar 系処女ラット（体重 150-200gm）に estradiol-17 $\beta, 10 \mu \mathrm{g}$ を皮下投与し，15時間後に動物を頸部脱臼により屠殺し，両側子宮角から既報 5 のでと く Kirby-Sugawa の hot phenol 法3)を用いて分離抽出した。 てのようにして得られた uterine high mole- 
cular RNA は，庶糖密度勾配法による分画パターンからみて，28S および $18 \mathrm{~S}$ の沈降係数を示す ribosomal RNA を主とする RNA であり，ての紫外線吸収曲線における吸光度のピークは $258 \mathrm{~m} \mu$ に認めら れた.

\section{II. 抽出 RNA 中の estrogenic contamination についての検索}

Uterine-RNA 中における estrogenic contamination の有無を検討する目的で，以下のような検枽を行 つた.

去勢ラットに estradiol-17 $\beta-6,7-{ }^{3} \mathrm{H} 5 \mu \mathrm{g}$ (Specific Activity 56Gi/mMol) を皮下投与し，15時間後に前 述の手技を用い uterine-RNA を抽出し，約 $1000 \mu \mathrm{g}$ の RNA を $1.0 \mathrm{ml}$ の生理食塩水に溶解，10ml の scintillation fluid を加えたのち, RNA 中の radioactivity を測定した. この結果抽出された high molecular RNA あるいは low molecular RNA 分画のいずれにおいても放射能は検出されなかつた (Table 1). なお前回のわれわれの検索結果によると, low molecular RNA は biologically inactive である.

Table 1. Fate of tritiated estradiol in recovery of RNA from rat uterus

\begin{tabular}{l|c|c}
\hline \multicolumn{1}{c|}{ Materials } & CPM & Percent of administered dose \\
\hline \hline H $^{3}$-Estradiol 5 $\mu \mathrm{g}$ & $1.4 \times 10^{7}$ & 100 \\
Uterine homogenate & 13,000 & 0.001 \\
Supernatant after phenol & 3,180 & $2 \times 10^{-4}$ \\
Precipitate after 70\% ethanol & 600 & $5 \times 10^{-5}$ \\
High molecular RNA & Nil & $\ldots$ \\
Low molecular RNA & Nil & $\ldots$ \\
\hline
\end{tabular}

Radioactivity of the extracted uterine-RNA was measured to rule out the possible estrogenic contamination.

Uterine-RNA was extracted 15hrs after subcutaneous injection of $5 \mu \mathrm{g}$ of estradiol$17 \beta-6,7-{ }^{3} \mathrm{H}$. Approximately $1000 \mu \mathrm{g}$ of RNA prepared was dissolved in $1.0 \mathrm{ml}$ of saline and $10 \mathrm{ml}$ of scintillation fluid was added. No radioactivity was detected both in high and low molecular RNA.

\section{Biologically active RNA の子宮腔内投与法}

Uterine-RNA は去勢ラット子宮腔内に次のような手順を用い注入した. すなわち hexobarbital を腹腔 内に投与し, 麻酔後開腹, 子宮頸部下の脂肪組織に 4 号絹糸を通し, てれを軽く前下方に牽引しながら子宮 角を挙上したのち，26 gauge 針を用い生理食塩水に溶解した RNA $100 \mu \mathrm{g}(0.02 \mathrm{ml})$, あるいは propylene glycol に溶解した estradiol-17 $\beta 2 \mu \mathrm{g}(0.02 \mathrm{ml})$ を子宮角腔内に卵管方向に徐々に注入した. 検体注入後, 子宮角が均等に膨隆するのを確認したのち注射針を抜去し，針挿入部より上部の子宮頸部を，あらかじめ通 しておいた前記の綃糸で結禁し，検体の流出を防止した. なおてのような機械的操作による子宮内膜の変化 を除外する目的で，対照として生理食塩水 $0.02 \mathrm{ml}$ を子宮角に注入した動物についても検討した.

\section{IV. 電顕的観察}

標本の作成にあたつては注射針の插入部を避け，子宮角の中 $1 / 3$ の組織のみを観察に供した.

動物は RNA, estradiol-17 $\beta$ 注入後それぞれ12時間，24時間後に hexobarbital 麻酔下で開腹し，子宮角 を摘出, リン酸緩衝液で $\mathrm{pH} 7.4$ 亿調整した paraformaldehyde (4\%). glutaraldehyde $(2.5 \%)$ 固定液に移 し, 固定液中で輪切し, 厚さ約 $1 \mathrm{~mm}$ の組織塊とし, さらに $2 \% \mathrm{OsO}_{4}$ で後固定を行つた. 次に組織をエ タノール系列で脱水し，エポキシ樹脂に包埋した．超薄切片は酢酸ウラニールと鉛の二重染色を行い，日立 HS-8 型電子顕微鏡を用い観察した. 


\section{観 察 結 果}

\section{I，去勢時内膜}

a) 表面上皮細胞 (Fig. 1).

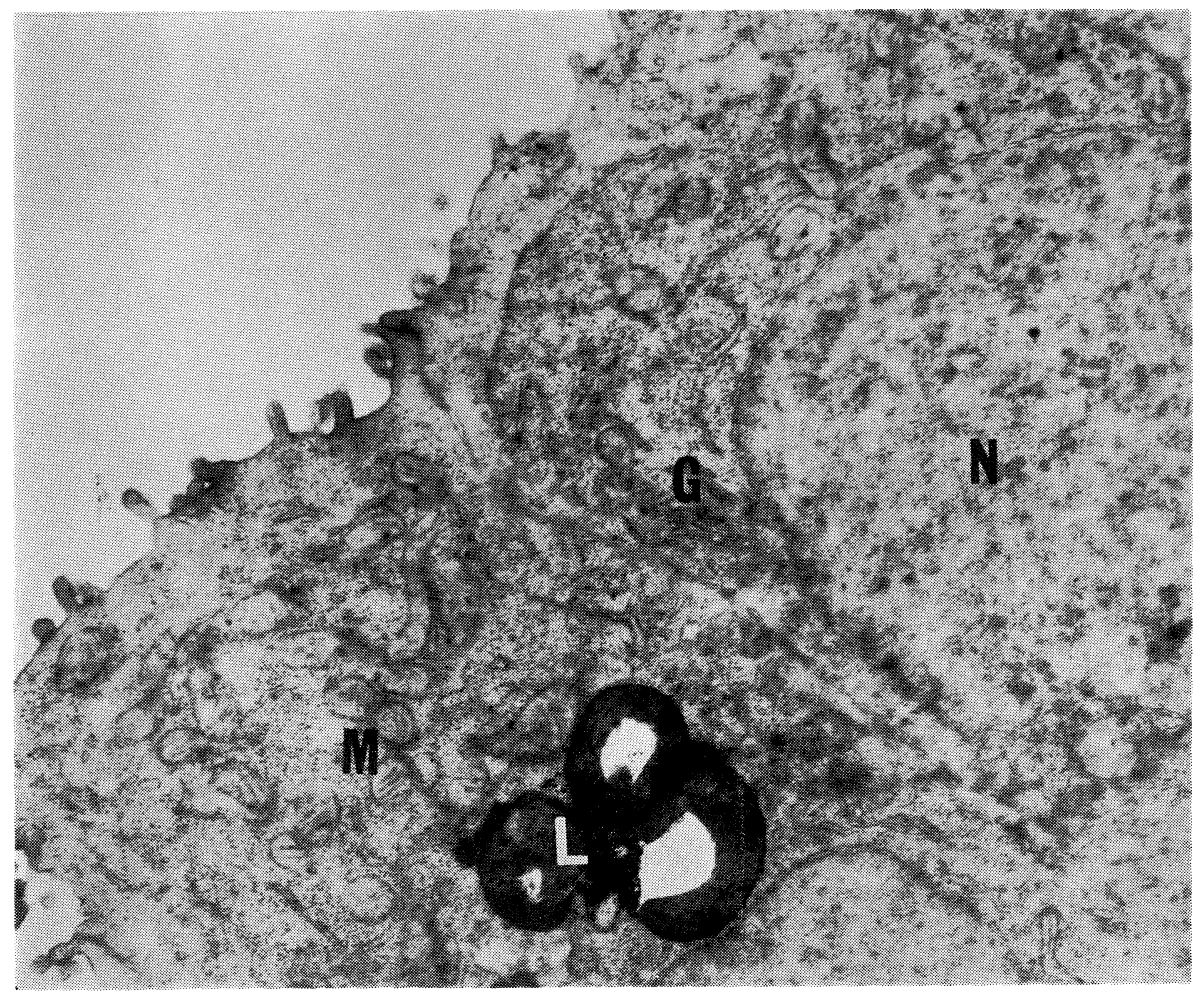

Fig. 1. Luminal epithelial cells in the ovariectomized rat.

The microvilli of the free surface are short and sparse. The Golgi complexes are small and the cisternae of the granular endoplasmic reticulum are not dilated. The mitochondria are also small and the electron density of the matrix matrial is low. A few lipid droplets of high electron density are seen in the supranuclear area. The ribosome is in the form of free ribosome. $\times 18,300 . \mathrm{N}$; nucleus, $\mathrm{G}$; Golgi complex, $\mathrm{M}$; mitochondrion, L ; lipid droplet.

表面上皮細胞は萎縮し，扁平 $(6-7 \mu)$ で，細胞質の大部分は核小体の不明膫な核によつて占められており，

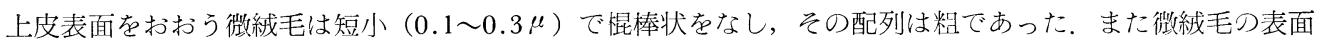
には微細毛状構造を認めなかつた。狭小な細胞質内においては小器官に乏しく, 縮小したゴルジ装置, 発達 の不良な粗面小胞体や，粗に分布する free ribosome が少数みられるのみである．乙の他細胞の基底部に おいては比較的電子密度の高い脂肪滴が中等数認められ，また同様な脂肪滴を核上部においても少数拝めた が, apical vesiclには観察されなかつた。ミトコンドリアも小型であり, その基質の電子密度も低かつた。

b ) 間質細胞

間質においては鬆粗化が著明であり, 間質細胞は表面上皮細胞同様, 細胞の大部分は核小体の不明膫な核 によつて占められ，狭小な細胞質には発達の悪いゴルジ装置や free ribosome が少数認められるのみであつ た。 


\section{Uterine-RNA 投与12時間後の内膜}

a) 表面上皮細胞 (Fig. 2).

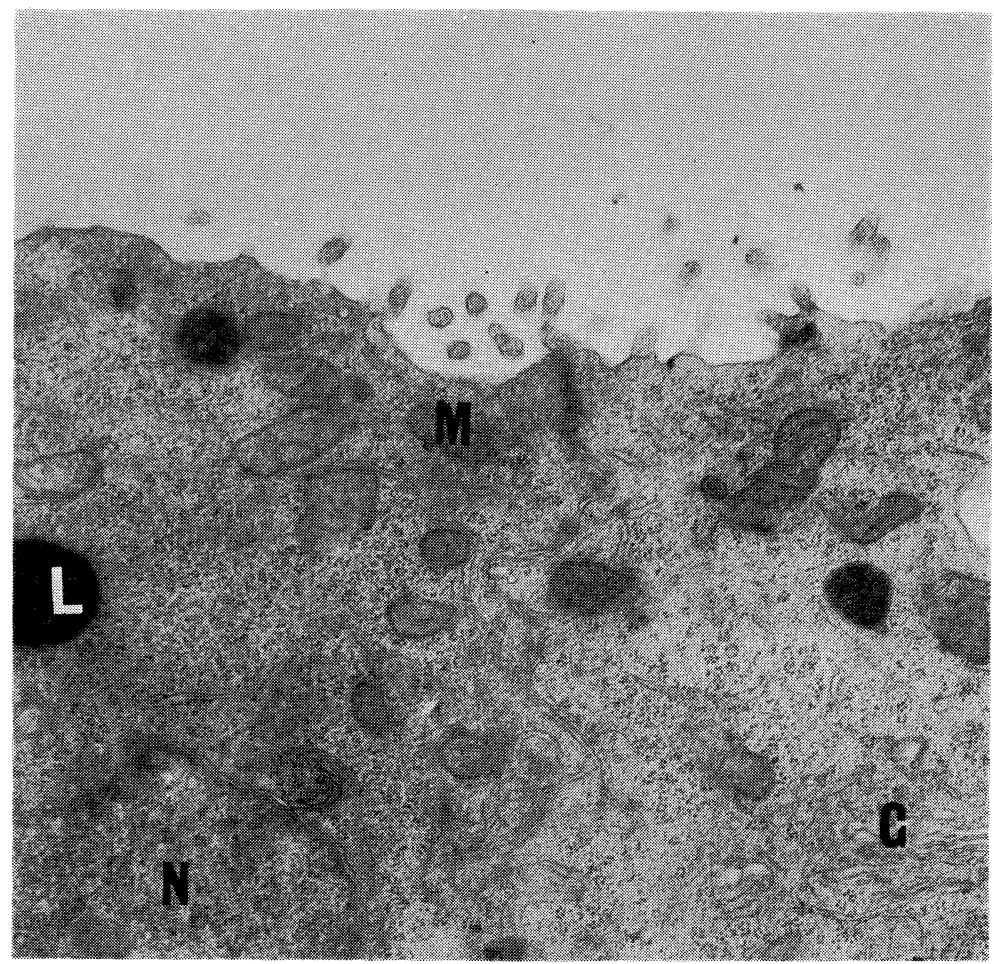

Fig. 2. Luminal epithelial cells at $12 \mathrm{hr}$ after the intraluminal injection of uterine-RNA.

The microvilli are taller and arranged more densely than those of the rat recieved saline. There are also some fuzzy coat observed along the microvilli.

The cisternae of the granular endoplasmic reticulum are moderately dilated.

Many ribosomes, most of them are in the form of polyribosome, and moderately developed Golgi complexes are observed. The mitochondria increase both in the size and the electron density of the matrix material. $\times 18,300 \mathrm{~N}$; nucleus, G ; Golgi complex, $\mathrm{M}$; mitochondrion, L ; lipid droplet.

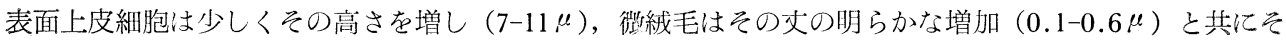
の配列も密となり，また表面の䘕細毛状構造も軽度ながら認められた．細胞質も全体として軽度肥大するが， apical vesicle は依然としてはとんど認められず，また pinocytotic vesicle も観察できなかつた。 又 free ribosome の分布は去勢時内膜上皮のそれに比し明らか滵で, polyribosome も出現し，それと共にゴルジ 装置の発達や, 内腔つやや拡大した粗面小胞体も観察された.

他方ミトコンドリアにおいても増大傾向が認められ，その基質の電子密度の増加がみられた。核はなお紐 胞の大部分を占めているが，核小体は明瞭となり，また増大していた．脂肪滴は主として基底部に限局して おり，軽度の減数がみられた。細胞間隙の掂大は認められなかつたが基底部細胞膜間の interdigitation は著明であつた。

b ）間質細胞

間質の鬆粗化は去勢時同様顕著であつたが，間質細胞の核小体は明暸となり，細胞質の軽度肥大も認めら 
れた。この他ゴルジ装置の軽度増大や粗面小胞体の内腔拡大も認められた。

III. Estradiol-17 $\beta$ 投与12時間後の内膜

a ) 表面上皮細胞 (Fig. 3).

このさいの表面上皮細胞にみられた諸変化は，uterine-RNA 投与12時間後にみられた前述の所見とほぼ 闰様であつた。

b ) 間質細胞

間質細胞における所見は uterine-RNA 投与群に比し，polyribossme の発達や精面小胞体の内腔拉大所 見がやや顕著であり，また脂肪滴も少数ながら観察された。

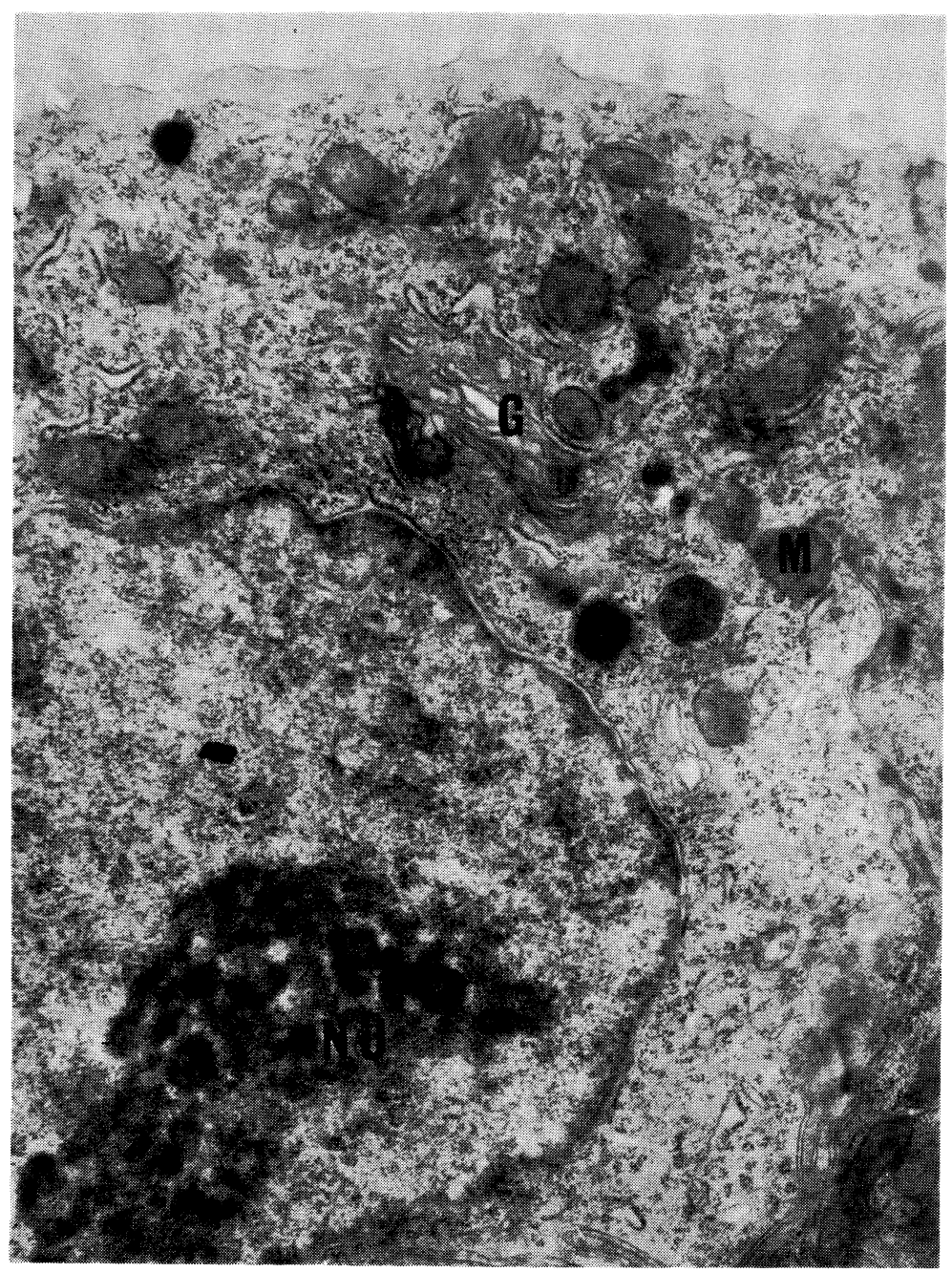

Fig. 3. Luminal epithelial cells at $12 \mathrm{hr}$ after the intraluminal injection of estradiol-17 $\beta$.

The similar pictures of the organelles as those of the luminal epithelial cells at $12 \mathrm{hr}$ after the intraluminal injection of uterine-RNA, shown in Fig. 2. are noted.

Well defined nucleolus is seen. $\times 18,300$.

G ; Golgi complex, M ; mitochondrion, NU ; nucleolus. 

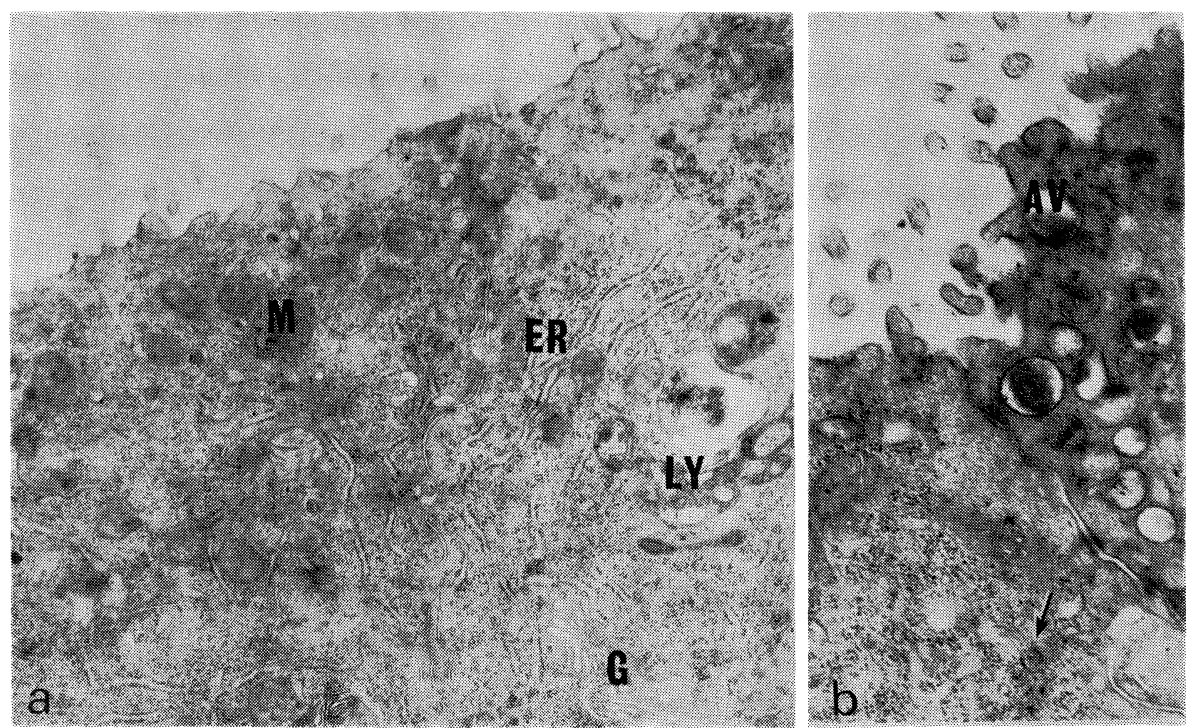

Fig. 4a. Luminal epithelial cells at $24 \mathrm{hr}$ after the intraluminal injection of uteirne-RNA. The tall microvilli and the fuzzy coat along them are obvious. Some apical vesicles are observed in the apical cytoplasm. The well developed network of the granular endoplasmic reticulum are also noted. $\times 18,300$.

M ; mitochondrion, ER ; granular endoplasmic reticulum, LY ; lysosome, G ; Golgi complex. Fig. 4b. Apical portion of the luminal epithelial cell at $24 \mathrm{hr}$ after the injection of uterine-RNA. Some apical vesicles contain the moderate electron-dense material. One ring-shaped polyribosome (arrow) is observed. $\times 28,800 . \mathrm{AV}$; apical vesicle.
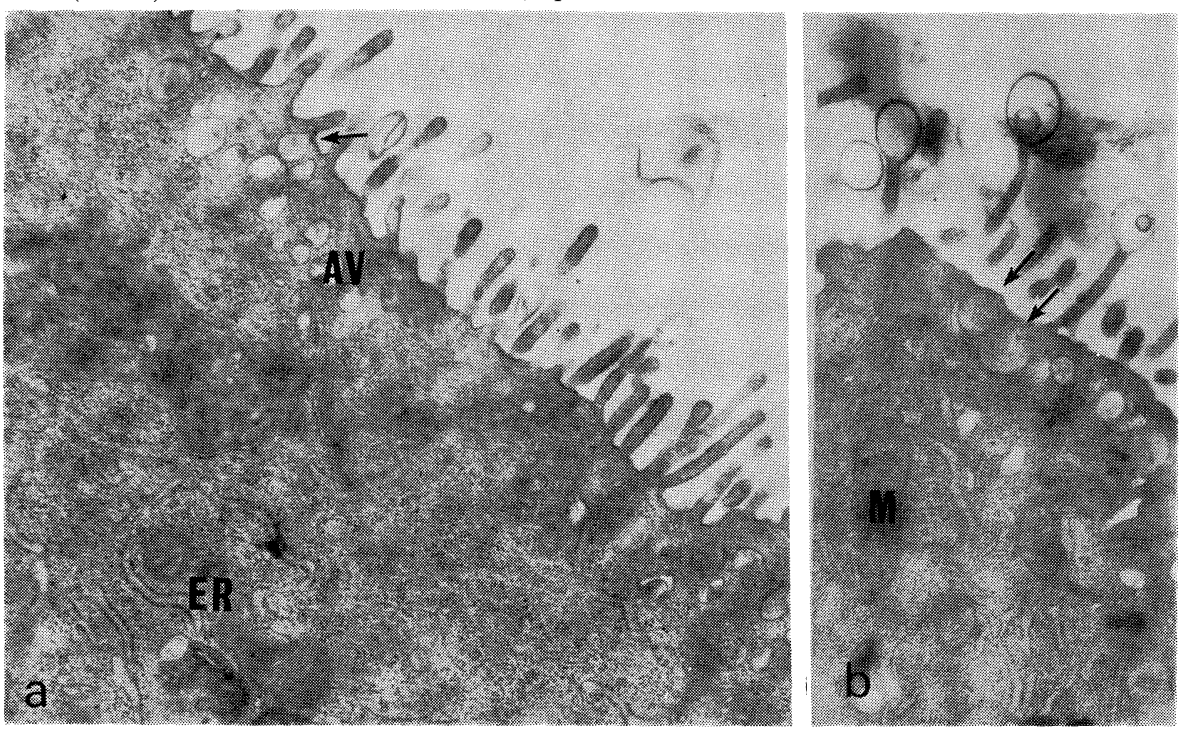

Fig. 5a. Luminal epithelial cells at $24 \mathrm{hr}$ after the intraluminal injection of estradiol-17 $\beta$. Dense arrangement of tall microvilli with fuzzy coat is remarkable. There are also several belb-like structures among the microvilli. Many apical vesicles are also seen. One apical vesicle (arrow) situates just beneath the free surface. $\times 24,000$.

AV ; apical vesicle, ER ; granular endoplasmic reticulum.

Fig. $5 \mathrm{~b}$. A pical portion of the luminal epithelial cell at $24 \mathrm{hr}$ after the injection of estradiol-17 $\beta$. Dilatation at the top of the tall microvilli, microapocrine-like structure, is observed, Some apical vesicles (arrows) have homogeneous material of low electron density and situate just beneath the free surface. $\times 24,000$. $\mathrm{M}$; mitochondrion. 


\section{Uterine-RNA 投与24時間後の内膜}

a ) 表面上皮細胞 (Fig. 4a, 4b, 6).

上皮細胞の高さは投与 12 時間後のそれと比較し 2 倍以上となり，上述の細胞質における小器官の諸変化も

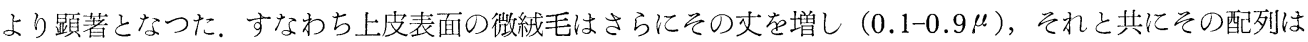

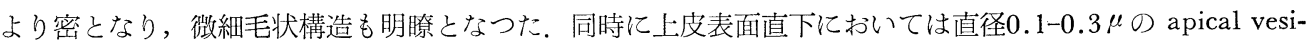
cle の出現が観察された。 そしててれらの apical vesicleの中には中等度の電子密度を呈する無構造の内容 を有するものや，細胞遊離表面にきわめて接近している小胞もみられた。 ミトコンドリアの大きさやゴルジ 装置の発達は12時間後のものと大差ないが，細胞質内の free ribosome は大部分 polyribosome を形成し， 中には円形やコイル状構造を呈するものも認められた。粗面小胞体の内腔拡大はより著明となり, 細胞質内 を縦横に走行しているのが観察された。

一般にライソゾーム系顆粒は增大し，ての他巨大なライソゾーム系顆粒，あるいは封入体を思わせる直径 $2 \mu$ にも達する構造も観察された.

核小体に関しては12時間後のものと著変はなく，また細胞間隙の搪大所見はての際にも明瞭ではなかつ た。しかしながら基底部細胞膜間における，相接する細胞間の interdigitation の像はより著明であつた。

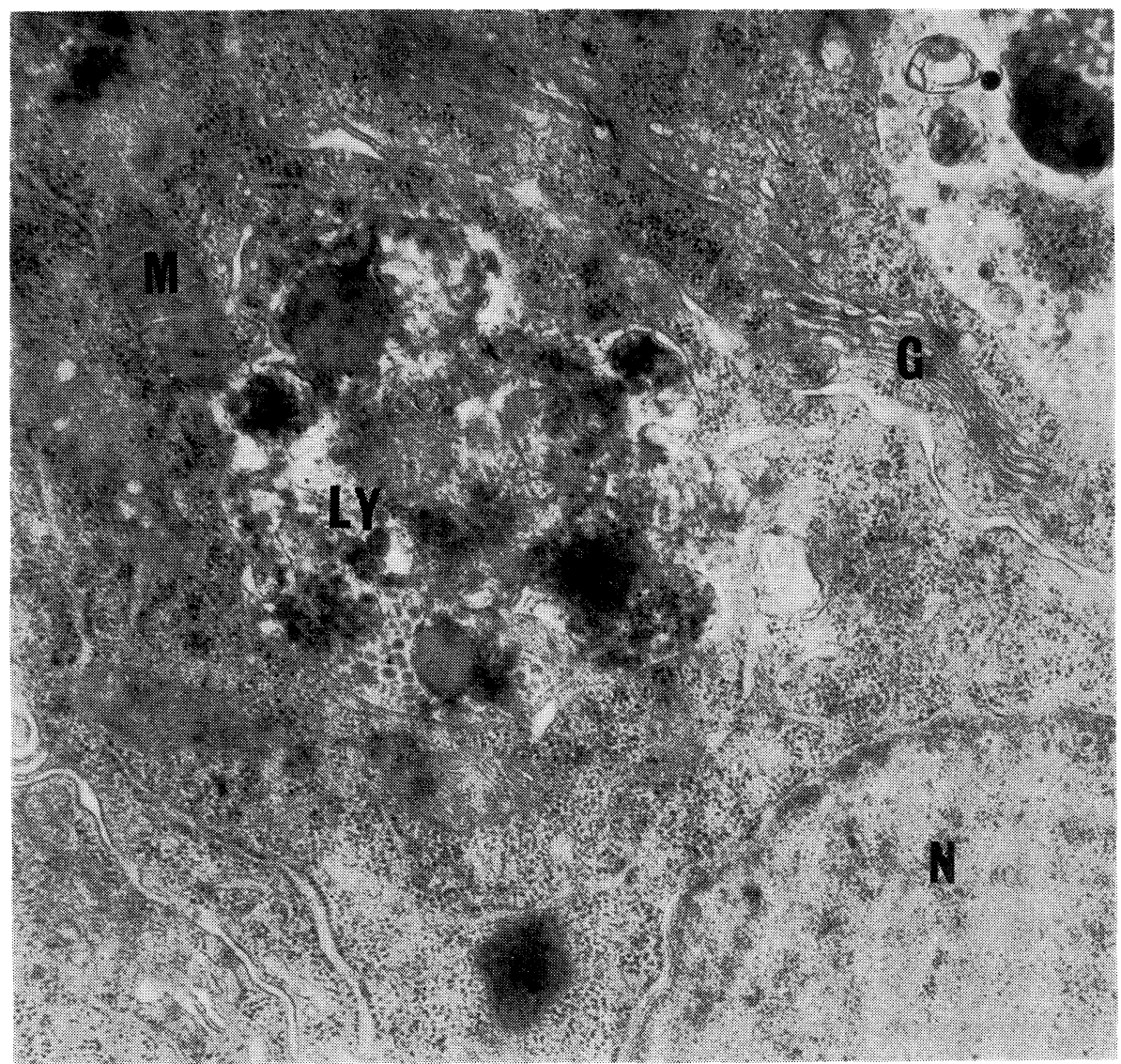

Fig. 6. Large lysosome in the luminal epithelial cell at $24 \mathrm{hr}$ after injection of uteirne-RNA. Large lysosome containing small granules and lipid droplet-like substances is shown. Part of another large lysosome is present in the right upper corner.

$\mathrm{M}$; mitochondrion, LY ; lysosome, G ; Golgi complex, $\mathrm{N}$; nucleus. $\times 28,800$. 


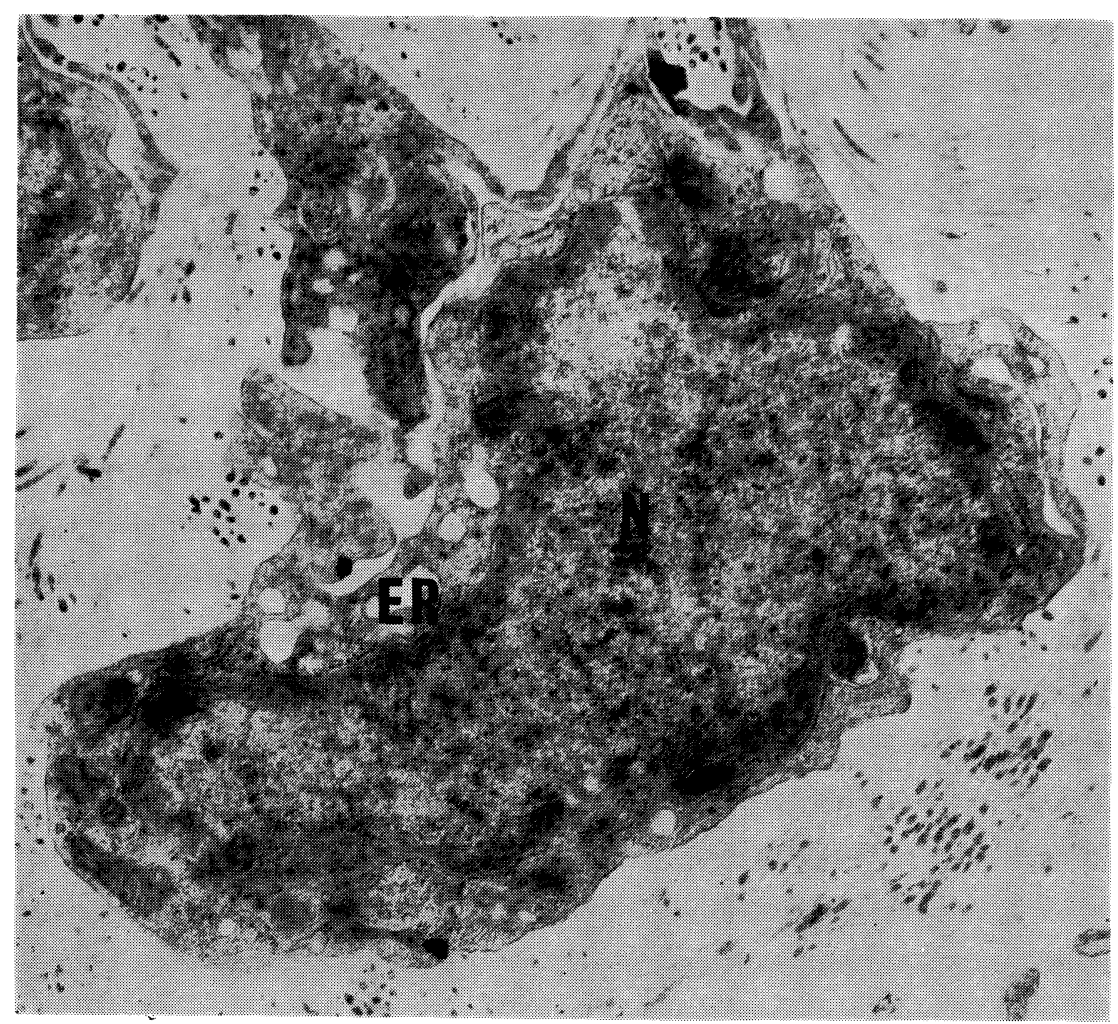

Fig. 7. Stromal cell at $24 \mathrm{hr}$ after the intraluminal injection uterine-RNA.

The cytoplasm is still atrophic but moderate dilatation of the cisternae of the granular endoplasmic reticulum is observed. $\times 18,300$.

ER ; granular endoplasmic reticulum, $\mathrm{N}$; nucleus.

なお基底部における pinocytotic vesicle は上皮表面同様，本実験条件下では認められなかつた。

b ）間質細胞 (Fig. 7.)

間質の鬆粗化はなお著明であつたが，間質細胞の細胞質は 12 時間後のものと比較しより増大し，また内腔 拡大を示す粗面小胞体の増数や，ゴルジ装置の軽度増大が認められた。 この他 polyribosome や脂肪滴も少 数認められた。

\section{Estradiol-17 $\beta$ 投与24時間後の内膜}

a ）表面上皮細胞 (Fig. 5a, 5b.)

このさいの表面上皮微細構造にみられる変化は, 同時期の uterine-RNA 投与群内膜のそれとほぼ同様で あつたが，微絨毛の配列は後者に比しより密であり，またその先端が膨大し，円形のポリープ状を呈するい わゆる microapocrine 分泌様形態を示すものがみられた。

なお大型ライソゾーム系顆粒と思われる構造の出現は RNA 投与群ほど明膫ではなかつた.

b ) 間質細胞 (Fig. 8.)

同時期の uterine-RNA 投与群内膜と比較し，細胞質肥大や粗面小胞体の内腔拡大の程度は，このさいの 間質細胞において，一層明暸であつた。 


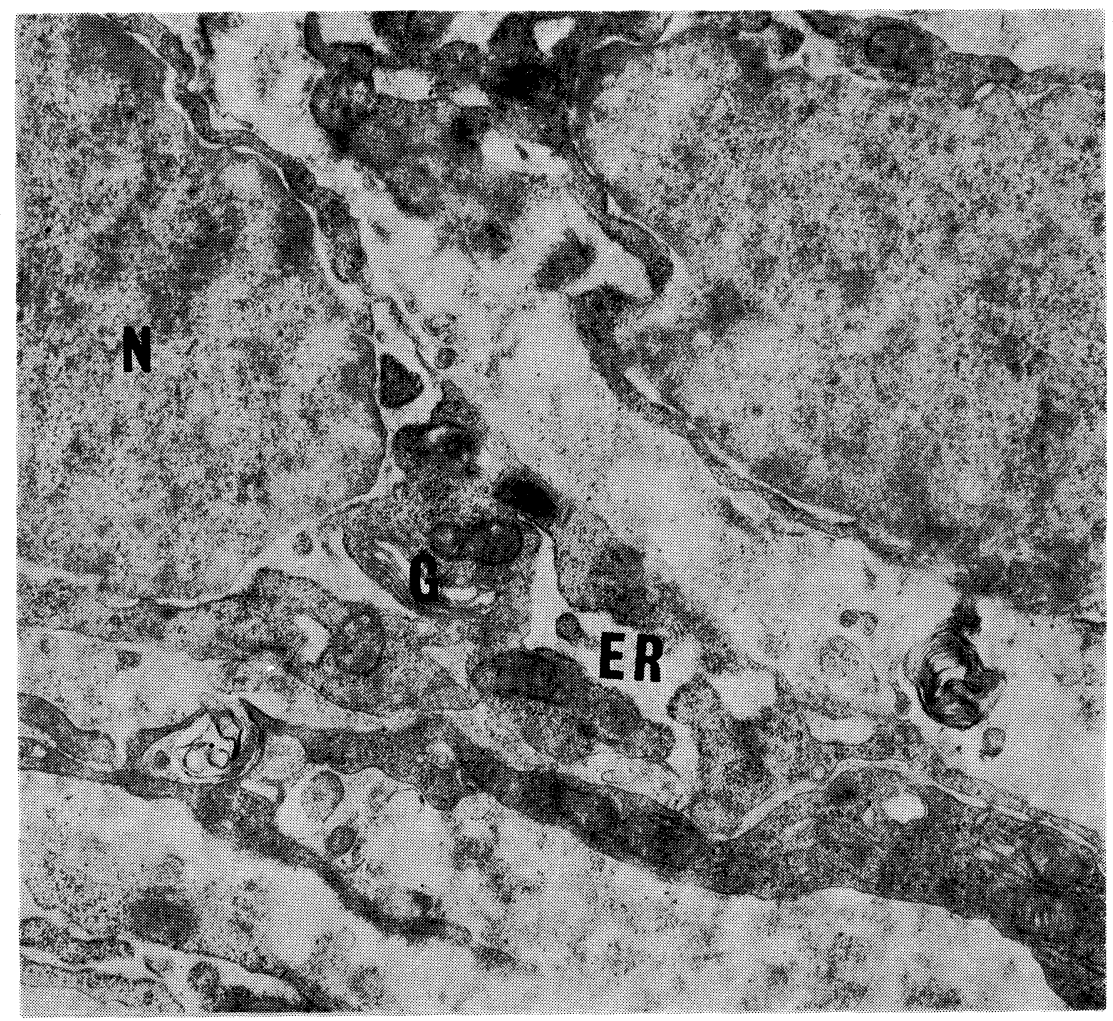

Fig. 8. Stromal cell at $24 \mathrm{hr}$ after the intraluminal injection of estradiol-17 $\beta$.

Moderate enlargement of the cytoplasm is noted. The dilatation of the cisternae of the granular endoplasmic reticulum is more prominent than those recieved uterine-RNA. $\times 18,300$. ER ; granular endoplasmic reticulum, G ; Golgi complex, N ; nucleus.

考按

以上のわれわれの成績は，いわゆる biologically active uterine-RNA が垫ラット子宮内膜細胞に対し， estradiol-17 $\beta$ 注入時とほぼ同様な微細構造の変化を誘起できるしとを示している.

すなわち表面上皮細胞では，まず12時間後に核小体の肥大，微䋘毛の延長，増加，ribosome の増加と共 に, polyribcsome の出現やゴルジ装置の発達などの諸変化をみ，つで24時間後には徴絨毛の一層の発達 と共に, polyribosome の増加, 粗面小胞体のより顕著な内腔拡大所見, さらに apical vesicle の出現か観 察された。

そしてこれらの変化は, estradiol-17 $\beta$ 投与群と比較して, 後者の 24 時間群において微縅毛のより密な配 列や microapocrine 分泌様形態の出現を認め得たという所見を除けば, 微細構造上の面においても両者間 に特に大差を認めなかつた。

他方表面下皮直上の間質細胞の形態に関しては，概して estradiol-17 $\beta$ 投与群においてより著明な細胞質 の肥大や粗面小胞体の内腔拡大が認められた。

とてろでこのような RNA の生物学的作用に関連してまず考慮されるべき問題は, RNA 中における estrogenic contamination の可能性である.

しかしこの点については，1）諸家の等しく涊めているょうに，RNA-ase 前処置高分子 RNA 投与下で 
は内膜上皮增殖能を失うという実験結果，あるいは，2）前述の ${ }^{3} \mathrm{H}$-estradiol 投与後の uterine high molecular RNA 中に放射能を検出し得ないという事実, さらに，3）RNA 抽出過程において， ethanol-ether 洗條を実施しても活性が失われないという Mansour ${ }^{9)}$ の報告などから考光てその可能性は低いものと思わ れる.国

次にてのような biologically active RNA 投与後に生ずる超微形態学的変化のうち，蛋白合成の場とし ての ribosome の推移に関しては, 投与12時間後に free ribosome の増加と共に polyribosome が形成さ れ，24時間後には分泌性蛋白合成の場としての粗面小胞体の内腔桩大像 と共に，てれら膜系と直結した

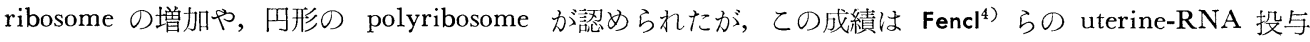
後の子宮性蛋白における標識アミノ酸の取り込みが，24時間後に最高に達するという生化学的な研究結果と ほぼ傾向を同じくするものと思われる。

さらに RNA 投与後に生ずるてのような蛋白合成能の充進に関連したもう一つの問題は， RNA 投与時 では estradiol-17 $\beta$ 投与時に比し，何らかの時間的な“ずれ”が認められても良いという考光方である。すな わち estrogen の作用機構に関しては, 現在細胞膜て到達した estrogen は cytosol receptor と結合し, つ

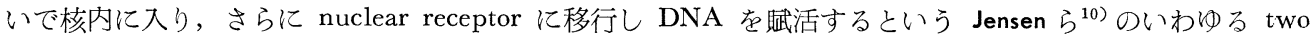
step mechanism が最有力視されており，こうした立場に立脚すれば uterine-RNA 投与下では，一応 estradiol-17 $\beta$ 投与時に比し，より速やかな蛋白合成の促進も予想できるからである.

しかしながら本研究においては，両者間の表面上皮細胞における蛋白合成の場としての ribosome, polyribosome, 粗面小胞体の増加や発達にあまり大差がなく，ての点に関する時間的な “ずれ”は必ずしも明膫 ではなかつた。

しかしての解明に関しては，今後，1）より細分化した time schedule を用いた実験や，同時に，2) このさいの核，核小体についての詳細な検討が不可欠であり，また，3）後述する如き理由から，両者間に おける分子量の相違に起因する細胞膜通過性の相違などについても考慮が払われなければならない.

他方微絨毛の変化化関しては，著者らは RNA 投与12時間後に微絨毛の増加，増長を観察できたが，本 成績は alkaline phosphatase 活性の主な局在の場が微縅毛であるととを考え合わせると, uterine-RNA を 去勢マウス子宮に注入し，その alkaline phosphatase 活性の増強を認め得たという Mansour ${ }^{11)}$ ，Yang $~{ }^{12)}$ の生化学的, あるいは組織化学的成績を裏付ける所見と考朰れる.

このほか内膜上皮にみられる微細構造の変化として, ゴルジ装置の肥大, 脂肪滴の減少, 細胞膜の interdigitation, さらに apical vesicle の出現，ライソゾーム系顆粒の増数を観察できたが，てのうち脂肪滴の 減少に逆比例して, 微絨毛の発達や細胞間間隙の著明な膜の interdigitation, あるいはその他の細胞内小器 官の発達を認めたことは，佐藤 ${ }^{13)}$ の指摘するように，膜系構成要素であるりン脂肪の増加が脂肪滴より転換 されるという可能性も除外できないものと思われる.

最後に子宮腔内に投与された uterine-RNA がどのような機序により上皮細胞内に入り，細胞增殖を誘起 するかについては，現在のとてろ詳細は不明である。しかしての点に関連して示唆に富む報告として，外因 性 RNA が哺乳動物細胞内に運般されるというAmos $~^{14)}$ ，Shanmugan $~^{15)}$ ，Wilson $~^{16)}$ のいくつかの報 告を指摘するととが可能である.

すなわち Amas ら ${ }^{14)} は$ ，大腸菌 RNA が chick embryo fibroblast に掑取されるてとを観察しており， また Shanmugan ら ${ }^{15)}$ は, ラット肝細胞より抽出された ${ }^{32} \mathrm{P}$ 標識 RNA を培養液に添加するととによつて, 浮遊肝実質細胞や肝組織内に取り込まれることを生化学的に証明しており，さらにラジオオートグラフを用 いた Wilson ら ${ }^{16)}$ の研究においては，RNA-like material か胚から内膜間質細胞に transport されること を観察している.

今回のわれわれの研究結果にわいては， macromolecule の上皮内掑取を直接示唆する形態像，すなわち pinocytosis 像を認めることはできなかつたが，われわれは去勢 progesterone 前処置下の子宮腔内に uterineRNA を投与した別途実験で間質細胞の增殖を認めており，こうした現象は RNA が何らかの経路で上皮 
細胞内に入り，さらに基底膜を通過し間質細胞に到達するととを具体的に示唆する一つの所見ではなからう かと推定している.

他方てのさい，仮りに ribosomal RNA が蛋白合成の律則作用を有するとすれば，子宮腔内に注入され た ribosomal RNA が胞体内に入り，とのため ribosomal RNA は增数し細胞の蛋白合成が充進するとい う解釈も可能である.

しかしながらてのような仮定に立てば，子宮以外の組織から抽出された RNAも内膜上皮の增殖を活性 化する筈であり, uterine-RNA の持つ臟器特異性を説明するととは困難であろう.

\section{結 語}

われわれは uterine-RNA の作用機序を形態学的に追求する一つの手段として, uterine high molecular RNA を去勢ラット子宮腔内に注入し, その内膜細胞に生ずる微細構造の変化を経時的に観察し, 次の所見 を得た。

表面上皮細胞では, RNA 投与12時間後に, 微絨毛の増数や増長がみられ, 細胞質の軽度肥大と共に free ribosome の増数, polyribosome の出現, さらには内腔の拡大した粗面小胞体や発達したゴルジ装置などが 認められた。 ての他ミトコンドリアの増大も観察され，また核小体も明瞭となつた。脂肪滴は去勢時内膜に 比し，軽度減数していた。.また基底部細胞間間隙の interdigitation は著明であつた。

次に RNA 投与 24 時間後では, より顕著な細胞質肥大と共に前述の諸変化は一㬝著明であつた。 さらに apical vesicle の出現, 巨大ライソゾーム系顆粒なども認められた.

この他予想される RNA の作用機構に関しても考察を加えた。

稿を終るにあたり，御指導，御校閲を睗つた東條伸平教授に深謝致します。

\section{文献}

1) Segal, S.J., Davidson, O.W. and Wada, K. : Proc. Nat. Acad. Sci. USA, 54 : 782, (1965). Unhjem, O., Attramadal, A. and Sölna, J. : Acta endocr., 58 : 227, (1968).

3) Sugawa, T. :

Steroid Hormones : Their Physiologic Significance in Reproduction, Report on the theme comissioned by Japanese Obstetrical and Gynecological Society (1970).

4) Fencl, M.M. and Villee, C.A.

: Endocrinology 88 : 279, (1971).

Tojo, S. : Endocrinol. Japon. $20: 517$ (1973).

Nat. Acad. Sci. USA, 58 : 2546, (1967).

5) Hayashi, K., Nishikawa, M., Lee, W., Takekida, H. and USA, $57:$ 1468, (1967).

8) Fujii, T. and Villee, C.A. : Proc. Nat. Acad. Sci. USA, 62 : 836, (1969).

9) Mansour, A.M. : Acta endocr., $57: 465$, (1968). T., Kawashima, T., Stumpf, W.E., Jungblut, P.W. and Desombre, E.R. : Proc. Nat. Acad. Sci. USA, $59: 632$, (1968).

11) Mansour, A.M. : Acta endocr., 54 : 541, (1967).

13）佐藤俊照 : 日産婦誌, 25 : and Hsü, G.Y. : Proc. Soc. Exp. Biol. Med., 133 : 485, (1970). 407, (1973).

14) Amos, H. and Kearns, K.E. : Exp. Cell. Res., $32: 15$, (1963). Shanmugan, G. and Bhargava, P.M. : Biochem. J., 99 : 297, (1966). Smith, M.S.R. : J. Reprod. Fert., 16 : 305, (1968).
16) Wilson, I.B. and 